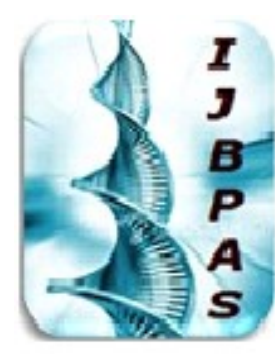

International Journal of Biology, Pharmacy and Allied Sciences (IJBPAS) 'A Bridge Betuen Caboratory and Q andor'

\author{
Www.iibpas.com
}

\title{
SOCIAL DETERMINANTS OF VOTING BEHAVIOUR IN KHYBER PAKHTUNKHWA: A CASE STUDY OF SELECTED DISTRICTS
}

\section{LAL BADSHAH ${ }^{*}$, PROF. DR. NIAZ MUHAMMAD ${ }^{2}$, AZIZULLAH JAN ${ }^{3}$, SHEHLA KHAN ${ }^{4}$ AND RAHAM ZAID ${ }^{5}$}

1: P.hD Scholar Sociology, University of Peshawar Pakistan, Phone: +0923461116226, Email: lbshah@hotmail.com

2: Chairman Department of Sociology, University of Peshawar, Phone: +923459393453, Email: niaz@uop.edu.pk

3: PhD Scholar Department of Sociology, University of Peshawar, Phone; +923454514903, Email: azizj153@gmail.com

4: Lecturer Department of Sociology, University of Peshawar, Email: shehlakhan@uop.edu.pk

5: PhD Scholar Department of Sociology University of Peshawar

*Corresponding Author

Received 11 ${ }^{\text {th }}$ Jan. 2019; Revised $4^{\text {th }}$ Feb. 2019; Accepted $20^{\text {th }}$ Feb. 2019; Available online $1^{\text {st }}$ July 2019

https://doi.org/10.31032/IJBPAS/2019/8.7.4760

\section{ABSTRACT}

This study was conducted on identifying the "Social Determinants of Voting Behaviour in Khyber Pakhtunkhwa: A Case Study of Selected Districts (2002-2013)". It is a quantitative study aimed at knowing the social factors of voting behaviour in the past three elections (2002, 2008 and 2013), with major purpose to see the changing trend in the mentioned elections. It was preceded with 292 respondents who had cast vote in any of the target elections and they were asked through Likert scale questionnaire under purposive sampling technique. The Study found a significant association of social factors such as family, biradari, feudalism, religion, political discussion at home and personal interests with voting behaviour. The changing scenario was observed as the importance of some factors was replaced by others. The study recommends that local political leadership as well as Election Commission of Pakistan should come forward to actively launch an awareness movement regarding the importance of vote towards increasing the participation ratio of voting especially women's voting.

Keywords: Voting Behaviour, Elections (2002-2013), Social Determinants, Khyber Pakhtunkhwa 


\section{INTRODUCTION}

Voting in national elections is the essence of democracy. A political system cannot be called democratic without public representation and participation. In representative democracies, people ensure their participation through vote casting which is considered an act that links polity with society. Elections ensure the right of the citizens to decide that who will govern them (Campbell \& David, 2008). Elections afford an opportunity to the citizens to indicate their priorities, interests and reservations (Chinsenga, 2006). Why and how the people vote in elections is called voting behaviour (Anderson \& Stephenson, 2010).

Although the importance of elections is globally accepted, however, elections in Pakistani context have special significance. Elections not only resulted in the creation of Pakistan but also in its break-up. In elections (1945-46) which was the last held in India, Pakistan got its independence; the 1970 elections, the first national elections of Pakistan, contributed to its break-up. The results of elections (1977) were charged as rigged which led to overthrowing of elected government and paved way for military regime. Gen. Zia got himself elected as the President in referendum and continued to rule for eleven years. The electoral history of
Pakistan has been turbulent. However, the subsequent elections of 1985, 1988, 1990 and 1997 remained peaceful and in each case peaceful transition of powers were observed (Wilder, 1999). The elected government of 1997 could not complete its tenure as the Nawaz Sharif-led government was overthrown by Gen. Pervez Musharraf, who clamped state of emergency and suspended the constitution. The military rule continued for around three years before general elections were held in October, 2002 which put the country again on democratic path and the successive elections of 2008 and 2013 further strengthened the democratic process (Asim, 2012). The electoral history of Pakistan is thus not too long. The first 23 years of Pakistan passed without national elections. Beside it, the delayed start of democratic process, the electoral system of Pakistan also experienced modifications. The frequent military takeover did not allow the representative democracy in Pakistan to flourish and strengthen (Ahmad, 2004). Each passing election reflected encouraging the turnout and remained remarkable in elections 2013 which was $55.83 \%$, the highest ever.

Elections manifest political behaviour of masses and help identify the factors as well as considerations that shape their 
political disposition and voting preferences. Voting behaviour means how and why people vote the way they do. Voting behaviour of voters in Khyber Pakhtunkhwa always stunned the analysts. Political history of the province reveals that different political parties came into power in different elections with split mandate and no political party has been able to form its government for the second term. PPP, PML (N), MMA, ANP, and PTI got success in the previous elections of 1993, 1997, 2002, 2008 and 2013 respectively (Zubair, 2013). Understanding voting behaviour in Khyber Pakhtunkhwa has, thus, become a complex puzzle. This study focused on the social factors that led the voters to change their voting choice each time. It is worth mentioning that an individual is the basic unit of democracy and voting behaviour of the province could not be explored until factors behind each vote decision are not identified. That's why utmost efforts were made to identify the social factors behind each vote decision to solve the puzzle of voting behaviour in Khyber Pakhtunkhwa.

\section{LITERATURE REVIEW}

Neither rich literature on the psephology of Pakistan is available nor has voting behaviour in Pakistan been studied at length. Extensive literature on the elections in Pakistan and voting behaviour of voters is not available. "Democratization in Pakistan: A study on 2002-Elections" by Mohammad Waseem, M. and "The Pakistani Voter: Electoral Politics and Voting Behaviour in the Punjab by Wilder, A. are however two extensive and book length studies available for guidance. The PH.D thesis of Ahmad, M. (2010) entitled "Electoral Politics in NWFP. 1988-1999", is another serious attempt in this regard. The rest of the studies are either local level or not containing enriched data.

The available literature depicts that social factors have an important role in voting behaviour in Pakistan having family as the more significant. Individuals' party identification is correlated with their parents' party identification. Voting choices and party preferences are associated with family background. Family is an agent of political socialization and a place of transmission of party affiliation to the youngsters (Erikson et al., 1980). According to Kanwal et al. (2016) youth are influenced by their parents' partisanship and inherit it. In Multan city, $30.8 \%$ respondents were influenced by their family in their voting choice. Javaid and Elahi (2014) found that $16 \%$ respondents in Lahore city voted a party just because their family voted the same party. Azeez et al. (2014) found that $34.4 \%$ respondents in 
District Layyah voted parties as desired by their parents. The Pakhtun Code of life (Pakhto) and paternal control have become social chains and a challenge for free elections in Khyber Pakhtunkhwa, where $12 \%$ women identified family pressure very important in their non-voting in previous elections (Ahmad, 2010). Biradari (Fraternity) is an important kinship system operating in Pakistan including Khyber Pakhtunkhwa (Wilder, 1999). Voting choice of $55 \%$ respondents is influenced by biradari (Mahmood et al., 2014). Javaid and Elahi (2014) found Biradari as decisive factor in the voting choice of $28 \%$ respondents. Azeez et al. (2014) found that $55 \%$ of the respondents chose to vote for the candidate of their own biradari in District Layyah. Gallup Pakistan (2008) reported that 9\% voters throughout Pakistan were biradaribound. The percentage of voting based on biradari is highest in Khyber Pakhtunkhwa i.e. $15 \%$. Biradari influenced voting behaviour in elections 1993, but with less importance beyond common belief (Wilder, 1999).

Religion could not be completely separated from politics. Both are closely related but this association is complex as well (Oshewolo, 2015). Political parties that follow religious agenda are supposed to be supported by conservative and religious people (Lillemets, 2015). In elections 2002, most of the support for MMA in Khyber Pakhtunkhwa came from rural dwellers, illiterate citizens, low income groups and housewives, which suggests that such categories have greater liking and affection for religion and support religious parties in elections (Farmanullah, 2014).

Although feudalism is weaning away from the world and middle class is entering politics, this ancient system still exists in Pakistan camouflaged in the disguise of democracy. Few thousand feudal control two-thirds of parliament (Sehgal, 2012). Most of the independent candidate in the assembly from KP return form southern and Northeastern areas which suggests that semifeudal and tribal social structures in these regions are still strong enough to influence voting behaviour of the people (Ahmad, 2010). Local feudal elites dominate in rural Punjab in particular and in Pakistan in general (Kaleem \& Ayaz, 2015).

\section{MATERIAL AND METHOD}

The study was carried out in seven districts of Khyber Pakhtunkhwa (one district from each division). The sampled districts were selected due to their major chunk of votes and relatively better understanding by the voters about the role and importance of 
vote. Registered voters aged 18 years who had cast vote in any of the sampled elections constitute the universe of this study. Multi Stage Sampling was used for data collection. At first instance, districts with major populace in all divisions of Khyber Pakhtunkhwa were identified by stratified sampling and then data was collected from sampled respondents under the purposive sampling technique. Proportional allocation strategy was applied for breakup of total sample size into target districts and respondents. It is noteworthy that sample size of 300 was chosen as per analogy of Roscoe (1975), however, during data collection, it was found that no woman voted in the sampled elections in district Dir upper, that is why 08 female voters distributed as per formula were not interviewed. So, total sample size of the study stands 292.

Table 1: Sample Composition and Selection Procedure

\begin{tabular}{|c|c|c|c|c|c|c|c|}
\hline \multirow{2}{*}{ S. No } & \multirow{2}{*}{$\begin{array}{l}\text { Sampled } \\
\text { Districts }\end{array}$} & \multicolumn{3}{|c|}{ Population Size (Registered Voters) } & \multicolumn{3}{|c|}{ Sample Size } \\
\hline & & Male & Female & Total & Male & Female & Total \\
\hline 1 & Peshawar & 819869 & 596646 & 1416515 & $\mathbf{5 0}$ & 36 & 86 \\
\hline 2 & Mardan & 577325 & 409797 & 987122 & 35 & 25 & 60 \\
\hline 3 & Abbottabad & 381617 & 293571 & 675188 & 23 & 18 & 41 \\
\hline 4 & Dir (Upper) & 205121 & 125883 & 331004 & 12 & $\mathbf{0}$ & 12 \\
\hline 5 & Kohat & 262303 & 188139 & 450442 & 16 & 11 & 27 \\
\hline 6 & D.I.Khan & 348697 & 280531 & 629228 & 21 & 17 & 38 \\
\hline 7 & Bannu & 270858 & 182683 & 453541 & 17 & 11 & 28 \\
\hline \multicolumn{2}{|c|}{ Total } & 2865790 & 2077250 & 4943040 & 174 & 118 & 292 \\
\hline
\end{tabular}

Data was collected through Likert Scale questionnaire. Univariate and bivariate analysis of the data was carried out. Chi-square test was used for bivariate analysis.

RESULTS AND DISCUSSION

\section{Demographic Information of the Respondents}

Respondents' minimum age was 18 years, being the least age limit for adult franchise in Pakistan. Age group of $10 \%$ respondents was $18-30$ years. Most of them voted first time being underage in the elections 2008 and 2002, but their inclusion in the study was essential to highlight the voting behavior of youth and maiden voters. Age of the remaining $90 \%$ respondents ranged from 31 years to above 70 years.
Educated respondents constitute $73 \%$, while uneducated constitute $27 \%$ of the sample size. As most of the sampled districts had major cities and urban centers, where the trend of and access to education is available, that's why majority of the respondents were educated. Rural residents constituted $67 \%$, while urban constituted $33 \%$ of the respondents. As peripheries constitute major portion of the constituencies, that's why the number of rural respondents is more than urban respondents. Moreover, $87 \%$ of the respondents were married while $13 \%$ were 
unmarried. Occupations of the respondents included government and private service (20\% and $16.5 \%$ respectively), Housewives (15\%), Business (13\%), Students (7.5\%), Manual Labour (7\%), Farming (6\%), Lawyers (6\%), Politicians (4\%), Journalists (2\%) and Religious Teachers (2.5\%).

Language of majority of the respondents (69\%) was Pashto, followed by Hindko (21\%) Saraiki (8\%) and Urdu (2\%). The Saraiki and Urdu speakers belonged to district D.I.Khan, Hindko speakers belonged to district Abbottabad, Peshawar and Kohat while Pashto speakers were distributed in all the sampled districts. However, all the respondents from district Dir Upper, Bannu and Mardan were Pashto speakers. As the province is mostly inhabited by Pathans and majority of the sampled districts are inhabited by purely Pashto speaking population, that's why major language of the respondents was Pashto. The inclusion of district Abbottabad, Kohat and Peshawar as area of the study justifies Hindko as the second major language of the respondents, whereas Saraiki with third language being spoken in district D.I.Khan. Majority of the respondents $(66 \%)$ belonged to joint family units, (24\%) had nuclear families, while (10\%) respondents had extended family units. Extended family units being major family pattern predicts the influence of family on the voting behaviour. Monthly family income of majority of the respondents (69\%) was Rs. 50,001/- to Rs. 65,000/-, while that of (31\%) was Rs. 5000/- to Rs. 50, $000 /-$ as per detail in the table 1.

\section{Denotations:}
A. Under age
B. Party
Boycotted
C.

Didn't like any party to vote for

F. Couldn't spare time to vote E. Family didn't allow to vote F. On election duty

Majority of the respondents 289 (99\%) cast vote in general elections 2013, while $03(1 \%)$ respondents didn't vote. 02 respondents (female) were not allowed by their family to cast vote and 01 respondent couldn't spare time for voting being on election duty. In elections 2008, 87\% respondents cast vote while $13 \%$ respondents didn't vote. Reasons for not voting were either being under-age ( $8 \%$ ), party boycott (3\%), could not spare time for voting either due to personal engagements or being on election duty $(1.2 \%)$, not allowed by family to vote $(0.4 \%)$, or dislike for the existing candidates or parties $(0.4 \%)$ and abstained from vote casting. In general elections 2002, $88.4 \%$ respondents cast their vote, while $(11.6 \%)$ didn't cast vote. Reasons for voting 
apathy were almost the same as in election 2008.

Association between Social Factors and Voting Behaviour:

Table 4 highlights the social factors that influences voters' choices. A highly significant association $(p=0.000)$ was recorded between personal decision and voting behaviour in the sampled elections. Percentage-wise, vote casting as personal decision increased with each passing election i.e. from $75 \%$ in 2002 to $77 \%$ in 2008 and further to $80 \%$ in election 2013 . It means that majority of the respondents in the province voted as per their own whim and desire without outside pressure and dictation. This freedom in voting choices could be attributed to increase in literacy rate, media exposure, and egalitarian culture of the province. Similarly, a strong association $(\mathrm{p}=0.000)$ was found between family and voting behaviour in the sampled elections. These findings are in line with the study results of Kanwal et al. (2016) who found significant association $(p=0.003)$ of family bond and authority of elders with voting behavior. These results are also in consonance with the study findings of Azeez et al. (2014); Durre-e-Shawar and Asim (2012) and Ahmad (2010). These findings corroborates the findings of Erikson et al. (1980) that individuals' party identification is significantly correlated with their parents' party identification. The Pakhtun Code of life (Pakhto) and paternal control in Khyber Pakhtunkhwa have become social chains and a challenge for free elections. Almost one third of the respondents in Hazara division of Khyber Pakhtunkhwa acknowledged the influence of family very important in their voting choices (Ahmad, 2010). However, family influence on voting decision declined with each successive election due to increase in education ratio, political awareness, exposure to mass media and weakening family bonds.

Biradari (Fraternity) is another unit of Pakistani society (Chaudhry et al., 2014). Biradari is an important kinship system operating in Pakistan including Khyber Pakhtunkhwa (Wilder, 1999). A significant association was found between biradari and voting behaviour in the sampled elections i.e. $(p=0.024)$ in election 2013, $(p=0.029)$ in 2008 and $(p=0.036)$ in 2002. These results match the Gallup Pakistan's Exit Poll Survey (2008) which reported that $9 \%$ voters throughout Pakistan were Biradari-bound. The results are also in accordance with research findings of Mahmood et al. (2014); Javaid and Elahi (2014); Azeez et al. (2014); Durr-e-Shawar and Asim (2012), and Ahmad (2008). Biradari system is still strictly in 
vogue and intricate in the electoral politics in areas like District Abbotabad and DIK. All political parties have grasped this trend in these districts and most often award tickets to candidates who belong to big biradaries. Party identification and ideological attachment is less important to voters than biradari. (Ahmad, 2010). Gallup Pakistan's Exit Poll Survey (1993) reported that biradari based voting reduced form $12 \%$ in 1998 , to $7 \%$ in 1990 and further to $6 \%$ in 1993 . The significance of biradari diminished due to intra-constituency biradari conflicts and rivalries (Wilder, 1999).

A non-significant association $(p=0.227)$ in 2013 and $(p=0.908)$ in 2008 was found between religion and voting behavior, however, both the variables were found significantly associated $(\mathrm{p}=0.007)$ in election 2002. Major reasons of greater religious influence on voting decision in election 2002 were the unity of six Islamic parties in the shape of MMA, USA attack on Afghanistan, Gen. Musharraf's support for USA and the political vacuum due to the forced asylum of the leaders of PPP and PML-N. The alliance launched a vigorous campaign arousing religious sentiments of the masses resulting into the success of MMA and formation of government in Khyber Pakhtunkhwa. In the subsequent elections, as no such religious issue existed to be exploited, the religious parties didn't fare well. Political parties that follow religious agenda and defend religious traditions are supposed to be supported by people who are traditional and religious in their outlook (Lillemets, 2015). Major support for MMA in 2002 elections came from rural respondents (50\%); house wives (69.8\%); low income respondents (39\%) and illiterate respondents (62.9\%) (Farmanullah, 2014).

Landlordism / feudalism and politics goes hand in hand in Pakistan (Perveen et al., 2014). Few thousand Feudal lords control almost two-thirds of parliament (Sehgal, 2012). A significant association between landlordism and voting behaviour was found in the sampled elections, i.e. $(p=0.048)$ in 2013; $(\mathrm{p}=0.034)$ in 2008 and $(\mathrm{p}=0.001)$ in 2002. These findings matches the study findings of Ahmad, (2010). Although the tempo of feudalism diminished with the passage of time in Pakistan, it is still part of the social structure of Khyber Pakhtunkhwa. Some parts of the province still reflects strong feudal tenant relationship. Petty local problems could easily be resolved by the elites which in turn demand political favours in the shape of vote. This relationship continues and so the vicious circle of feudalism. The data suggest that local 
landlords do influence voting choice of the people (Ahmad, 2010). Most of the independent candidates in the assembly from Khyber Pakhtunkhwa return from southern and Northeastern areas of the province which suggests that semi-feudal and tribal social structures in these regions are still strong enough to influence voting behaviour of the people (Ibid: 334). A highly significant association was found between personal favours by the party/candidates to the respondents and their voting behaviour in the sampled elections i.e. $(p=0.001)$ in 2013, $(p=0.000)$ in 2008 and (0.001) in 2002. These results are supported by the Gallop Pakistan, 1990 and 1993 Exit Poll Surveys, which shows that patronage and personal favours were the most desired qualities of the candidates for voters. These results supports Wilder (1999), that voting behaviour in
Pakistan is influenced by voters' desire for the resolution of local and personal issues, personal favours, provision of help in ensuring local utility services and backing in affairs related to local government departments. Majority of votes are thus collected by the candidates who are skilled on these fronts. A highly significant association $(\mathrm{p}=0.002)$ in $2013 ;(\mathrm{p}=0.010)$ in 2008 and $(\mathrm{p}=0.001)$ in 2002 was found between frequent political discussion at home and voting behaviour of the respondents. Politics is a favourite topic of discussion in gatherings in Pakistan. People keep themselves abreast of political information. Such discussion is more common in families who are politically affiliated and enthusiastic. Political discussion at home is an effective tool to politically socialize members of the family.

Table 2: Demographic Information of the Respondents

\begin{tabular}{|c|c|c|c|c|c|}
\hline Age Group (in years) & Frequency & Percentage & Education Status & Frequency & Percentage \\
\hline 18 to 30 & 29 & 10 & Primary & 6 & 2 \\
\hline 31 to 40 & 37 & 12.5 & Middle & 9 & 3 \\
\hline 41 to 50 & 90 & 31 & Matric & 30 & 10 \\
\hline 51 to 60 & 78 & 26.5 & Intermediate & 24 & 8 \\
\hline 61 to 70 & 47 & 16 & Graduation & 55 & 19 \\
\hline Above 70 & 11 & 4 & M.A/MSc & 57 & 20 \\
\hline Total & 292 & 100 & LLB & 17 & 06 \\
\hline Marital Status & Frequency & Percentage & Medical Doctors & 14 & 05 \\
\hline Married & 254 & 87 & Uneducated & 80 & 27 \\
\hline Single & 38 & 13 & Total & 292 & 100 \\
\hline Total & 292 & 100 & Area of Residence & Frequency & Percentage \\
\hline Occupation & Frequency & Percent & Urban & 95 & 33 \\
\hline Farming & 17 & 6 & Rural & 197 & 67 \\
\hline Manual labour & 20 & 7 & Total & 292 & 100 \\
\hline Business & 38 & 13 & $\begin{array}{l}\text { Monthly Family } \\
\text { Income (in PKR) }\end{array}$ & Frequency & Percentage \\
\hline Government Service & 58 & 20 & $5000-20,000$ & 7 & 2 \\
\hline
\end{tabular}




\begin{tabular}{|c|c|c|c|c|c|}
\hline Private Service & 49 & 16.5 & $20,001-35,000$ & 34 & 12 \\
\hline Religious Teachers & 7 & 2.5 & $35,001-50,000$ & 49 & 17 \\
\hline Lawyers & 17 & 6 & $50,001-65,000$ & 66 & 23 \\
\hline Journalists & 6 & 2 & $65,001-80,000$ & 61 & 21 \\
\hline Politicians & 13 & 4 & Above 80,000 & 75 & 26 \\
\hline Students & 22 & 7.5 & Total & 292 & 100 \\
\hline Housewives & 45 & 15.5 & Mother Tongue & Frequency & Percentage \\
\hline Total & 292 & 100 & Pashto & 202 & 69 \\
\hline Family Pattern & Frequency & Percentage & Urdu & 5 & 1.5 \\
\hline Nuclear Family & 69 & 24 & Hindko & 61 & 21 \\
\hline Joint Family & 194 & 66 & Saraiki & 23 & 8 \\
\hline Extended Family & 29 & 10 & Punjabi & 1 & 0.5 \\
\hline Total & 292 & 100 & Total & 292 & 100 \\
\hline
\end{tabular}

Source: Field Survey, (2016)

Table 3: Respondents' Voting Ratio in the Sampled General Elections

\begin{tabular}{|c|c|c|c|c|c|c|}
\hline \multirow{2}{*}{ Voting in General Elections } & \multicolumn{2}{|c|}{ Voted } & \multicolumn{2}{|c|}{ Not Voted } & \multicolumn{2}{|c|}{ Total } \\
\hline & Frequency & \%age & Frequency & \%age & Frequency & \%age \\
\hline Elections 2013 & 289 & 99 & 3 & 1 & 292 & 100 \\
\hline Elections 2008 & 254 & 87 & 38 & 13 & 292 & 100 \\
\hline Elections 2002 & 258 & 88.4 & 34 & 11.6 & 292 & 100 \\
\hline Reasons for not Voting & $\mathbf{A}$ & B & $\mathbf{C}$ & D & $\mathbf{E}$ & $\mathbf{F}$ \\
\hline Elections 2013 & $\mathbf{0}$ & $\mathbf{0}$ & $\mathbf{0}$ & $\mathbf{0}$ & $2(0.7 \%)$ & $1(0.3 \%)$ \\
\hline Elections 2008 & $23(8 \%)$ & $10(3 \%)$ & $1(0.4 \%)$ & $1(0.4 \%)$ & $1(0.4 \%)$ & $2(0.8 \%)$ \\
\hline Elections 2002 & $32(11 \%)$ & 0 & $\mathbf{0}$ & $1(0.3 \%)$ & 0 & $1(0.3 \%)$ \\
\hline
\end{tabular}

Source: (Field Survey, 2016)

Table 4: Association Between Social Factors and Voting Behaviour

\begin{tabular}{|c|c|c|c|c|c|c|}
\hline Statement & Election & Agree & Dis-agree & Not Sure & Total & Chi-Square \\
\hline \multirow{3}{*}{$\begin{array}{c}\text { Selecting a party or } \\
\text { candidate to vote for was } \\
\text { your personal decision. }\end{array}$} & 2013 & $231(80 \%)$ & $52(18 \%)$ & $6(2 \%)$ & $289(100 \%)$ & $39.748(0.000)$ \\
\hline & 2008 & $195(77 \%)$ & $53(21 \%)$ & $6(2 \%)$ & $254(100 \%)$ & $66.581(0.000)$ \\
\hline & 2002 & $193(75 \%)$ & $5822.5 \%)$ & $7(2.5 \%)$ & $258(100 \%)$ & $45.566(0.000)$ \\
\hline \multirow{3}{*}{$\begin{array}{c}\text { Selecting a party or } \\
\text { candidate to vote for was } \\
\text { personal decision shared } \\
\text { with family }\end{array}$} & 2013 & $194(67 \%)$ & $93(32 \%)$ & $2(1 \%)$ & $289(100 \%)$ & 45.321(0.000) \\
\hline & 2008 & $209(82 \%)$ & $43(17 \%)$ & $2(1 \%)$ & $254(100 \%)$ & $32.050(0.000)$ \\
\hline & 2002 & $220(85 \%)$ & $36(14 \%)$ & $02(1 \%)$ & $258(100 \%)$ & $21.198(0.000)$ \\
\hline \multirow{3}{*}{$\begin{array}{c}\text { Selecting a party or } \\
\text { candidate to vote for was } \\
\text { your biradari decision }\end{array}$} & 2013 & $28(9.5 \%)$ & $24(83.5 \%)$ & $20(7 \%)$ & $289(100 \%)$ & $11.200(0.024)$ \\
\hline & 2008 & $26(10 \%)$ & $212(84 \%)$ & $16(6 \%)$ & $254(100 \%)$ & $10.781(0.029)$ \\
\hline & 2002 & $27(10.5 \%)$ & $215(83.5 \%)$ & $16(6 \%)$ & $258(100 \%)$ & $10.308(0.036)$ \\
\hline \multirow{3}{*}{$\begin{array}{l}\text { Your voting choice has been } \\
\text { influenced by your religion }\end{array}$} & 2013 & $14(4.5 \%)$ & $274(95 \%)$ & $1(0.5 \%)$ & $289(100 \%)$ & $5.649(0.227)$ \\
\hline & 2008 & $9(3.5 \%)$ & $244(96 \%)$ & $1(0.5 \%)$ & $254(100 \%)$ & $1.009(0.908)$ \\
\hline & 2002 & $27(10.5 \%)$ & $231(89.5 \%)$ & 0 & $258(100 \%)$ & $9.872(0.007)$ \\
\hline \multirow{3}{*}{$\begin{array}{c}\text { Your voting choice has been } \\
\text { influenced by your } \\
\text { Landlord } \\
\end{array}$} & 2013 & $11(4 \%)$ & $278(96 \%)$ & $\mathbf{0}$ & $289(100 \%)$ & $6.068(0.048)$ \\
\hline & 2008 & $12(5 \%)$ & $242(95 \%)$ & $\mathbf{0}$ & $254(100 \%)$ & $6.751(0.034)$ \\
\hline & 2002 & $12(5 \%)$ & $246(95 \%)$ & 0 & $258(100 \%)$ & $13.070(0.001)$ \\
\hline \multirow{3}{*}{$\begin{array}{l}\text { The candidate gave } \\
\text { personal favours to } \\
\text { you/your family }\end{array}$} & 2013 & $81(28 \%)$ & $193(67 \%)$ & $15(5 \%)$ & $289(100 \%)$ & $18.299(0.001)$ \\
\hline & 2008 & $98(38.5 \%)$ & $141(55.5 \%)$ & $15(6 \%)$ & $254(100 \%)$ & $22.762(0.000)$ \\
\hline & 2002 & $85(33 \%)$ & $154(60 \%)$ & $19(7 \%)$ & $258(100 \%)$ & $18.393(0.001)$ \\
\hline \multirow{3}{*}{$\begin{array}{l}\text { Your family members often } \\
\text { discuss politics at home }\end{array}$} & 2013 & $15(5 \%)$ & $259(90 \%)$ & $15(5 \%)$ & $289(100 \%)$ & $16.528(0.002)$ \\
\hline & 2008 & $13(5 \%)$ & $227(90 \%)$ & $14(5 \%)$ & $254(100 \%)$ & $13.266(0.010)$ \\
\hline & 2002 & $16(6 \%)$ & $227(88 \%)$ & $15(6 \%)$ & $258(100 \%)$ & $17.649(0.001)$ \\
\hline
\end{tabular}

Source: (Field Survey, 2016) 


\section{CONCLUSION}

Family, biradari, feudalism, religion and personal favours were identified as important social determinants effecting voting behaviour in Khyber Pakhtunkhwa. The percentage of voting based on personal choices increased in every election. Among social determinants, family stands with greater significance. Although diminishing, is still more influential than other factors. Biradari was also important but restricted to some areas only. Feudalism did influence voting choice but was not so significant because of egalitarian culture of the province. Personal favours by the candidates was found significant because of voters concerns over assistance in local issues. Religion was significant in election 2002 but its influence substantially declined subsequently. Voting behaviour, thus, doesn't depend on any sole social factor rather each vote decision is a composite of several factors that explains how and why a person votes the way that he or she chooses. The collective influence of all social factors lead the voters to set their political preferences and make voting choices. Although political factors also influence voting choices, however most of the political determinants are based on social determinants, such as party affiliation originates from family, socialization and norms. These are social factors that determine political preferences of the voters. It is thus safe to conclude that social factors are stronger determinants of voting behaviour in the province of Khyber Pakhtunkhwa.

Based on findings of the study, it is recommended that voters' education and political awareness is essential to discourage group prejudices and empower individual voters to make voting choices independently. The election commission of Pakistan should take strict measures to ensure that at no one who is eligible and willing to cast vote is barred by anyone from voting. Any political party restricting female voters to access to polling station must be banned to participate in any election for at least 05 years. All parties may be bound to have women wings in their offices orbit and they should mobilize the women to vote in favour of any contesting candidate.

\section{REFERENCES}

[1] Ahmad, M. S. (2010). Electoral Politics in NWFP. 1988-1999 (Doctoral dissertation, Ph. D. diss., National Institute of Pakistan Studies, Ouaid-i-Azam University, Islamabad), 2-137.

[2] Ahmed, M. (2004). Faisalabad Division ke Siasat per Biradarism 
kay Asraat. (Doctoral dissertation), BZU University, Multan. 46.

[3] Anderson, C. D., \& Stephenson, L. B. (2010). The puzzle of elections and voting in Canada. Voting behaviour in Canada. Toronto: UBC Press. 1-14.

[4] Asim, M. (2012). Voting behavior of people towards different political parties in district Faisalabad, Pakistan. Mediterranean Journal of Social Sciences, 3 (2), 86-87.

[5] Azeez, F., Ashraf, C. A., Juni, M. S., Haider, I., Ali, M. M., \& Kareem, J. (2014). Biradrism as Stronger Determinant of Voting Behavior: Exploring the Voting Behavior of People Towards Different Political Parties During Election 2013 in District Layyah. International Journal of Innovation and Applied Studies, 9(4), 1773.

[6] Campbell, David F. J. (2008). The Basic Concept for the Democracy Ranking of the Quality of Democracy. Vienna: p.3.

[7] Chaudhry, A. G., \& Ahmed, A. (2014). Biradari's Function and Significance: An Anthropological
Study of Gender Opinions. Lahore:

Science International, 26(4), 1863.

[8] Durre-e-Shawar and Asim, M. (2012). Voting behavior of people towards different political parties in district Faisalabad, Pakistan. Mediterranean Journal of Social Sciences, 3 (2), $\quad$ 86-87.

[9] ECP (2013). General Elections 2013. Report: Pakistan: (Volume II. p.5.). $\quad$ Retrieved from http://www.ecp.gov.pk. May 13, 2016.

[10] Erikson, R. S., Luttbeg, N. R., \& Tedin, K. L. (1980). American Public Opinion. Toronto: John Wiley and Sons, 301.

[11] Farmanullah (2014).

Operationalizing the Theory of Party Identification in the Electoral Politics of Khyber Pakhtunkhwa: A Case Study of General Elections 2002. Journal of Research Society of Pakistan. 51 (1), 87-105.

[12] Gallup Pakistan, (2008). Understanding Elections in Pakistan: Elections 2008. Exit Poll Election Day Survey. 21-41.

[13] Gallup Pakistan, (1993). Pakistan At The Polls 1993: Gallup Political 
weather Report. Special Issue 1993,

Islamabad: 38-39.

[14] Gallup Pakistan, (1990). Pakistan At The Polls 1990: Gallup Political weather Report. Special Issue 1990, Islamabad: 29-57.

[15] Javaid, U., \& Elahi, U. (2014). Patterns of Political Perceptions, Attitudes and Voting Behaviour: Influence of Media. Lahore: South Asian Studies, 29(2), 372-373.

[16] Kaleem, M., \& Ayaz, M. (2015). Biradri (Clan) as Stimulus to Vote in Rural Punjab (A Case Study of PP 40 Khushab 2. The Government-Annual Research Journal of Political Science.4(4), $182-88$

[17] Kanwal, L., Shahid, A. R., \& Naeem, M. (2016). Voting Behaviour of Educated Youth in Pakistan: A Study of Multan City. Journal of the Research Society of Pakistan,53(2). 9198.

[18] Lillemets, J. (2015). Social divisions defining voting behavior: Impact of cleavages on party choice (Mastre's dissertation). Estonia: Institute of Government and Politics, University of Tartu, 4-29.
[19] Mahmood, B., Sohail, M. M., Mushtaq, S. K., \& Rizvi, S. A. (2014). Social Factors Hindering Political Participation in Pakistan: A Review Article. Mediterranean Journal of Social Sciences, 5(23), 1936.

[20] Oshewolo, R. M., \& Maren, B. A (2015). Religion and Politics in Nigeria. International Journal of Politics and Good Governance 6 (3), $1-3$.

[21] Perveen, S., \& Dasti, H. A. (2014). Feudalism: A Pastime of Power, Economic and Political influence in Pakistan. Pakistan Vision, 15(1), 62.

[22] Roscoe, J. T. (1975). Fundamental Research Statistics for the Behavioral Sciences (2 ${ }^{\text {nd }}$ Edition) New York: Holt, Rinehart and Winston.

[23] Sehgal, E. I. (2012, March 8). Feudalism stunts democracy. The News. Retrieved from https://www.thenewsstraem.com.

[24] Wilder, R .A. (1999). The Pakistani Voter: Electoral Politics and Voting Behaviour in the Punjab. Karachi: Oxford University Press. 149-211. 
[25] Zubair, A. (2013). 15 May

Wednesday). Khyber Pakhtunkhwa upheld the tradition of political change. Daily Times, (15 May Wednesday), p. 9. 